\title{
Notice of Books Received
}

As previously announced, with this issue we adopt a policy of providing brief notifications of books received in the last four years. Each notice will not exceed 150 words.

Here, we provide details of three books for which we have received notices from authors or publishers, along with a list of the books we have reviewed since 2014. As also mentioned, books for which notices are provided may be reviewed in a later issue.

Hample, Dale (2018) Interpersonal Arguing. New York: Peter Lang. pp. 301.

This book is an accessible review of scholarship on key elements of face-to-face arguing, which is the interpersonal exchange of reasons. Topics include frames for understanding the nature of arguing, argument situations, serial arguments, argument dialogues, and international differences in how people understand interpersonal arguing. This is a thorough survey of the leading issues involved in understanding how people argue with one another.

VAN Eemeren, Frans. H. (2018) Argumentation Theory: A Pragma-Dialectical Perspective. Argumentation Library series. Springer. pp.199.

The book offers a compact but comprehensive introductory overview of the crucial components of argumentation theory. In presenting this overview, argumentation is consistently approached from a pragma-dialectical perspective by viewing it pragmatically as a goal-directed communicative activity and dialectically as part of a regulated critical exchange aimed at resolving a difference of opinion. The book also systematically explains how the constitutive parts of the pragma-dialectical theory of argumentation hang together. 
The following topics are discussed: (1) argumentation theory as a discipline; (2) the meta-theoretical principles of pragma-dialectics; (3) the model of a critical discussion aimed at resolving a difference of opinion; (4) fallacies as violations of a code of conduct for reasonable argumentative discourse; (5) descriptive research of argumentative reality; (6) analysis as theoretically-motivated reconstruction; (7) strategic manoeuvring aimed at combining achieving effectiveness with maintaining reasonableness; (8) the conventionalization of argumentative practices; (9) prototypical argumentative patterns; (10) pragma-dialectics amidst other approaches.

HiтchCоск, DAVID. (2017). On Reasoning and Argument: Essays in Informal Logic and Critical Thinking. Cham, Switzerland: Springer. Pp. xxvii, 553.

This book brings together in one place David Hitchcock's most significant published articles on reasoning and argument. In seven new chapters he updates his thinking in the light of subsequent scholarship. Collectively, the papers articulate a distinctive position in the philosophy of argumentation.

Among other things, the author:

- develops an account of "material consequence" that permits evaluation of inferences without problematic postulation of unstated premises.

- updates his recursive definition of argument that accommodates chaining and embedding of arguments and allows any type of illocutionary act to be a conclusion.

- advances a general theory of relevance.

- provides comprehensive frameworks for evaluating inferences in reasoning by analogy, means-end reasoning, and appeals to considerations or criteria.

- argues that none of the forms of arguing ad hominem is a fallacy.

- describes proven methods of teaching critical thinking effectively. 
Olmos, Paula (Ed.). (2017). Narration as Argument. Cham, Switzerland: Springer. Pp. xii, 1-234.

This collection of essays has achieved to gather an international group of scholars, mainly, but not exclusively, from the field of Argumentation Theory, and put together an anthology of eleven original chapters on Narration as Argument from different perspectives. It presents reflections on the relationship between narratives and argumentative discourse, focusing on their functional and structural similarities and dissimilarities, and offering diverse conceptual tools for analyzing the narratives' potential power for justification, explanation and persuasion. The first Part, under the title "Narratives as Sources of Knowledge and Argument", includes five chapters addressing general, theoretical and philosophical issues, related to the argumentative analysis and understanding of narratives. The second Part, entitled "Argumentative Narratives in Context", brings us six more chapters that concentrate on either particular functions played by argumentatively-oriented narratives or particular practices that may benefit from the use of special kinds of narratives.

RAZINSKY, HiLI (2017) Ambivalence: A philosophical exploration. London \& New York: Rowman and Littlefield London: pp. 296.

This book studies the relations between rationality and ambivalence (mental conflict). Ambivalence and its forms are central to subjectivity and communication, action and judgement. Defending a Davidsonian view about the constitutive rationality of mental attitudes, it argues that ambivalence is an important form of basic (constitutive) rationality and mental unity. Ambivalence can be irrational in a secondary sense, as in weakness of the will and selfdeception. It can also be highly rational, including forms of appropriate significant action with both opposed poles. Ambivalence of belief is possible, ordinary, basically rational and central to the logic of belief. The rationality of deliberation is also bound up with ambivalence. Rather than being the agnostic consideration of 
propositions or practical options, deliberation usually assumes and employs ambivalence, and may aptly end with it.

Gilbert, Michael A. (2014). Arguing with People. Peterborough, ON: Broadview Press. Pp. 1-137.

Arguing with People brings developments from the field of Argumentation Theory to bear on critical thinking in a clear and accessible way. This book expands the critical thinking and shows how those tools can be applied in the hurly-burly of everyday arguing. Gilbert emphasizes the importance of understanding real arguments, understanding just who you are arguing with, and knowing how to use that information for successful argumentation. Interesting examples and partner exercises are provided to demonstrate tangible ways in which the book's lessons can be applied. Arguing with People is an excellent addition or add-on for any Critical Thinking course. "Addressed to students, it is clearly and engagingly written. ... I recommend assigning this book as supplementary reading for a critical thinking course and also for an informal logic course." - J. Anthony Blair, University of Windsor

Wohlrapp, Harald R.. (2014) The Concept of Argument. A Philosophical Foundation, Dordrecht: Springer (lxii+443 pages)

The book is an attempt to revise and update our traditional understanding of argument. It is motivated by an awareness of some specificities which are not covered in the traditional theories - these are mainly two: the dynamics of argument and its subjective dimension. Their lack seems to be due to an underdeveloped understanding of the general "reflective" nature of argumentation. The present approach is based on a merger of pragmatist and dialectical philosophy. In the book the various aspects of the update are tackled in a sequence of 10 chapters, starting with "Knowledge" and ending at "Transsubjectivity". 


\section{Books reviewed since 2014}

Blair, J. A. (2012). Groundwork in the Theory of Argumentation: Selected Papers of J. Anthony Blair. Argumentation Library, Vol. 21. Dordrecht: Springer. Pp. xxi, 1-355.

Finocchiaro, Maurice A. (2013). "Meta-argumentation, An Approach to Logic and Argumentation Theory." Studies in Logic, Logic and Argumentation, Vol. 42. London: College Publications. Pp. vii, 1-279.

Macagno, Fabrizio and Douglas Walton. (2014). Emotive Language in Argumentation. New York: Cambridge.

Rubinelli, Sara and A. Francisca Snoeck Henkemans (Eds.). (2012). "Argumentation and Health." Special issue of the journal Argumentation in Context, Vol. 1, No. 1. Amsterdam: John Benjamins. Pp. vi, 1-142.

Eemeren, Frans H. van and Bart Garssen (Eds.). (2015). Reflections on Theoretical Issues in Argumentation Theory. Cham: Springer International Publishing. Pp. xiv, 1-293.

Amossy, Ruth. (2014). Apologie de la polémique. Paris: Presses universitaires de France. Coll. L'interogation philosophique. Pp. $1-240$.

Gilbert, Michael A. (2014). Arguing With People. Peterborough, ON: Broadview Press. Pp. 1-12, front matter; 13-137.

Campbell, John Angus, Antonio de Velasco and David Henry (Eds.). (2016). Rethinking Rhetorical Theory, Criticism, and Pedagogy: The Living Art of Michael C. Leff. East Lansing, MI: Michigan State University Press. Pp. xxiv, 1-481.

Hitchcock, David. (2017). On Reasoning and Argument. Cham: Springer International Publishing. Pp. xxvii, 1-553.

Tindale, Christopher W. (2015). The Philosophy of Argument and Audience Reception. Cambridge: Cambridge University Press. Pp. xii, 1-244. 